\title{
From colonial fortresses to neoliberal landscapes in Northern Tanzania: a biopolitical ecology of wildlife conservation
}

\author{
Jevgeniy Bluwstein ${ }^{1}$ \\ University of Copenhagen, Denmark
}

\begin{abstract}
Drawing on critical debates in political ecology and biopolitics, the article develops a "biopolitical ecology of conservation" to study historical shifts in how human and nonhuman lives come to be valued in an asymmetric way. Tanzania and the so-called Tarangire-Manyara Ecosystem illustrate how these biopolitical shifts became entangled with conservation interventions and broader visions of development throughout colonial and postcolonial history. Colonial efforts to balance seemingly competing domains of human and nonhuman species through spatial separation gave way to the development of the post-colonial nation through the nurturing of its wildlife population. This shift from human-nonhuman incompatibility towards human dependency on wildlife and biodiversity conservation culminated in the contemporary biopolitical ecology and geography of landscape conservation. Landscape conservation seeks to entangle human and nonhuman species. Through conservation, human populations are rearranged and fixed in time and space to allow wildlife to roam free across unbounded spaces. This conservation governmentality is tied to global environmentalist concerns and political economies of neoliberal conservation, as well as to a domestic agenda of tourism-based economic growth. It secures land tenure for some, while imposing a biopolitical sacrifice on the rural population as a whole. This forecloses alternative rural futures for a land-dependent and increasingly land-deprived population.
\end{abstract}

Keywords: landscape conservation, colonialism, post-colonialism, human and animal geography, biopolitics, governmentality, Tanzania, Tarangire

\section{Résumé}

S'appuyant sur des débats critiques en écologie politique et en biopolitique, une «écologie biopolitique de la conservation» est utilisée pour étudier les changements historiques dans la manière dont les vies humaines et non humaines sont valorisées de manière asymétrique. La Tanzanie et l'écosystème dit Tarangire-Manyara illustrent comment ces changements biopolitiques se sont mêlés aux interventions de conservation et aux visions plus larges du développement dans l'histoire coloniale et post-coloniale. Les efforts coloniaux pour équilibrer des domaines apparemment opposés d'espèces humaines et non humaines à travers la séparation spatiale ont cédé la place au développement de la nation post-coloniale, à travers le développement de sa population faunique. Cette évolution vers la dépendance envers la faune et la conservation de la biodiversité a abouti à l'écologie biopolitique contemporaine et à la géographie de la conservation du paysage. Il entremêle des espèces humaines et non humaines. Grâce à la conservation, les populations humaines sont réorganisées et fixées dans le temps et dans l'espace pour permettre à la faune de se déplacer librement dans des espaces sans limite. Une gouvernementalité de la conservation est liée aux préoccupations environnementales globales et aux économies politiques de la conservation néolibérale, ainsi qu'à un programme national d'obtention de devises étrangères basées sur le tourisme. Il sécurise le régime foncier pour certains, tout en imposant un sacrifice biopolitique à la population rurale dans son ensemble. Cela exclut les alternatives rurales pour une population dépendante de la terre et de plus en plus privée de terres.

${ }^{1}$ Dr. Jevgeniy Bluwstein, Global Development Section, University of Copenhagen, Denmark. Email: jevgeniy "at" ifro.ku.dk, j.bluwstein "at" gmx.de. Jevgeniy has a Ph.D. in political ecology of conservation and development from the University of Copenhagen. His research interests lie at the intersections of environmental and social development and change, spanning the fields of human geography, political ecology, political economy and anthropology, with a particular focus on Tanzania. His research has been published in Geoforum, World Development, Conservation and Society, Conservation Biology and the Journal of Agrarian Change. This article benefited from comments by Kasper Hoffmann, Jens Friis Lund, Mattias Borg Rasmussen and an anonymous reviewer. Jevgeniy is indebted to his research assistants, interview partners and everyone who shared their time and insights. 
Mots-clés: conservation du paysage, colonialisme, post-colonialisme, géographie humaine et animale, biopolitique, gouvernementalité, Tanzanie, Tarangire

\section{Resumen}

Con base en debates críticos en ecología política y biopolítica, propongo una ecología biopolítica de conservación como marco analítico para el estudio de cambios históricos en cómo la vida de humanos y no humanos son valoradas de formas asimétricas. Con el caso de Tanzania ampliamente, y con una iniciativa concreta de conservación en lo particular (el llamado ecosistema Tarangire-Manyara), ilustro cómo estos cambios biopolíticos se entrelazan con intervenciones de conservación y más amplias visiones de desarrollo rural y nacional a través de historia colonial y post-colonial. En la historia, esfuerzos coloniales para equilibrar los dominios humanos y de especies no humanas en visible competencia a través de la separación espacial, dieron paso al desarrollo de la nación post-colonial al facilitar el aumento de la vida silvestre. Este cambio de percibir el destino de humanos y no humanos como ajeno uno del otro, hacia una dependencia en la conservación de vida salvaje y biodiversidad, culmina en una ecología biopolítica y geografía de la conservación de paisaje que con la que convergen los futuros de humanos y especies no humanas. A través de la conservación de paisajes, las poblaciones humanas se acomodan y fijan en el tiempo y el espacio, para permitir que la vida silvestre tenga libre acceso a espacios abstractos sin límites. Esta gubernamentalidad de conservación va, al mismo tiempo, a la par con intereses ambientalistas globales y economías políticas de conservación neoliberal, así como con una agenda doméstica de crecimiento económico a través de intercambio extranjero basado en el turismo. Así se asegura la tenencia de la tierra para algunas personas, mientras que se impone un sacrificio biopolítico a la población rural como totalidad, excluyendo así, futuros rurales alternativos a una población que depende de la tierra y que poco a poco se le ha privado de esta.

Palabras clave: conservación del paisaje, colonialismo, post-colonialismo, geografía humana y animal, biopolíticas, gubernamentalidad, Tanzania, Tarangire

\section{Introduction: from elephant population control to a limitless elephant population}

In early 2016 I had a conversation with a park warden about the elephant dilemma in Tarangire National Park, a protected area in Northern Tanzania. Looking back at the original design of Tarangire that was created as a Game Reserve in 1957 and expanded to a park in 1970, the park warden observed that "Tarangire was designed badly. It is too narrow, elephants can cross from farm to farm [located] on both edges of the park" (Interview 2016). Indeed, based on a census conducted in 2014, the national park is believed to host around 3,300 elephants in the dry season, when wildlife congregates inside the park around a perennial water source, the Tarangire River. This represents the highest density in any protected area in Tanzania (1.2 elephants $\left./ \mathrm{km}^{2}\right)$ and the highest number of elephants recorded in the area since the 1990s (TAWIRI 2015). What is more, today the elephant population significantly exceeds a 'desired upper population' of 0.75 elephants $/ \mathrm{km}^{2}(2,000$ elephants) that a Ministerial report proposed in 1994 (MNRT 1994). What do park authorities intend to do today about this apparent excess beyond the upper population limit? In the last decades the idea of an upper population limit gave way to a powerful consensus that elephants must be protected beyond the park boundaries across a vast landscape to roam free. Another park warden exemplified this consensus by pointing out that in case of "too many elephants [in Tarangire], they will spread to Manyara, [Lake] Natron etc. ${ }^{2}$ That's why the protection of the migration corridors is important. We want them to be as protected as in the Tarangire National Park" (Interview 2016).

I was startled by the shift in perception over the desired elephant population density from being limited in the 1990s to being unlimited today, and by the apparent lack of concern over rural livelihoods. Peoples' farms are increasingly raided by growing elephant herds in the region. Beyond food security, the conflict between rural livelihoods and elephants runs deeper. Doing fieldwork in villages adjacent to Tarangire National Park, I was often confronted by people who would lament that "if an elephant is killed, the entire district government comes here. But if people or livestock are killed, nobody comes" (Interview 2015). This is a remarkable

\footnotetext{
${ }^{2}$ Lake Natron is located next to the Kenyan border, more than a hundred kilometres away from Tarangire.
} 
historical shift, given that the protected area was created by the colonial administration to contain wildlife and to control its population in order to protect its colonial subjects from it (Arlin 2011; also see Garland 2006). How did it come to a point when rural people living around Tarangire feel abandoned by public authorities, who in return, as I will show, perceive rural livelihoods as threats to Tarangire's survival as a tourism wilderness attraction and as a pillar of national development? How and when did the idea to "roll back the boundaries" for elephants (AWF 2004: 18-19) and to let them roam free become so dominant around Tarangire, and indeed across Tanzania?

To explain this historical shift and to illustrate its contemporary implications, I offer a biopolitical analysis of colonial and post-colonial wildlife preservation and conservation in Tanzania, thereby pursuing two interrelated objectives. Firstly, drawing on recent debates on green governmentality and biopolitics (Biermann and Anderson 2017; Biermann and Mansfield 2014, Cavanagh 2014; Lorimer 2015; Nel 2015; Rutherford 2007) my theoretical-analytical ambition is to situate a historical political ecology (Offen 2004) of wildlife conservation interventions (Brockington 2002; Neumann 1998) in its biopolitical context to highlight the changing role that preservation and conservation rationalities and initiatives have played in governing rural people, wildlife and spaces in a shifting biopolitics of "making live" and "letting die." Secondly, I advance a much needed and slowly emerging political ecological critique of the nascent but growing landscape conservation approach to illustrate what kind of biopolitical rationalities emerge in this conservation governmentality (Clay 2016; McCall 2016; Waage and Benediktsson 2010).

\section{Towards a biopolitical ecology of wildlife conservation}

A governmentality lens offers an analytic of the waxing and waning of dominant rationalities of rule, or government. Its intellectual forerunner Michel Foucault highlighted a historical shift in how sovereign power over life and death - so dominant in medieval Europe - gave way to questions of how to govern entire populations effectively without a necessary recourse to coercion by the threat of punishment (Foucault [1978] 1991; Foucault 2003). Entire populations became objects of modern technologies of rule (governmentality) through knowledge production in the form of statistics, medical, and other state sciences. Power over life itself, or biopower, came to be exercised when concerns with the reproduction and management of individual behavior and entire populations took central stage in governmental projects. This politics of life, understood as anatomopolitics of the human body and biopolitics of the population (Rabinow and Rose 2006), built upon certain ways of knowing, seeing, and ruling over nature through particular technologies and experts (Rutherford 2007). The combination of technology, knowledge and expertise converged in the exercise of biopower to make live and to let die (Foucault 2003). Whose lives would become nurtured (made live), and whose abandoned (let die), came to depend on historically contingent rationalities of government. Recent scholarship goes beyond Foucault's exclusive focus on humans in suggesting that these rationalities reflect a biopolitics of "differently racialized" and "asymmetrically valued populations of humans and nonhumans" (Cavanagh 2014: 273, see also Biermann and Mansfield 2014: 257; Srinivasan 2014), and even cut across differently valued nonhuman lives and communities (Collard and Dempsey 2013). Importantly, rather than substituting sovereign power, the exercise of biopower as an effect of a modern governmentality of nature-society relations continues to be 'permeated' by sovereign power (Biermann and Mansfield 2014: 270; Foucault 2003: 241; Rutherford 2007).

Looking beyond the western world, governmentality and biopolitics offer a powerful analytic of colonial and postcolonial political ecological histories across sub-Saharan Africa (Death 2016). By reordering a socialecological landscape into bounded spaces for people and wildlife, the unruly and supposedly uncivilized human subjects of a colonial governmentality were to be disciplined, made productive and rendered legible to the state, while wildlife could be more effectively controlled and accessed (Neumann 2004a; Scott 1998). The construction of biopolitically relevant differences has been at the forefront of a colonial governmentality (Cavanagh 2016; Li 2014). With the onset of colonial rule, people and wildlife became classified, categorized and essentialized into populations with distinct properties and clearly delineated territories (e.g. the "Maasai Reserve"). Africans have been perceived - along fixed tribal lines - as primitives, noble savages, iconic warriors, natural conservationists or environmental destroyers. Wildlife has been categorized as vermin, as problem animals, game, as invasive, flagship or charismatic species. In this article I chart how these conflicting 
discourses and perceptions underpinned historically evolving and shifting biopolitical strategies of spatialized population control and fed into governmental attempts to move people and wildlife around and to fix them in space (Hodgson 2001; Neumann 2004a).

Socially constructed differences within and across the human and nonhuman domains have advanced a western dichotomy of nature and culture, imposing it on colonial subjects (West, Igoe, and Brockington 2006). Where certain ethnic groups could not be unambiguously defined as cultural beings, they were treated as being closer to animals than to humans, becoming enveloped into 'nature.' Due to their seemingly harmless conduct vis-à-vis the environment, these so-called primitive yet noble savages were deemed compatible with their environment, could be "conserved" with the rest of nature as "fauna" and were thus tolerated within enclosed reserves (Neumann 1998). Such paternalistic and racialized liberalism towards colonial subjects was entangled in the pursuit of economic objectives. Simply put, colonial subjects were not allowed to change their 'nature' to be allowed to stay (Li 2014; West, Igoe, and Brockington 2006; Willems-Braun 1997).

Several biopolitical strategies for wildlife preservation and conservation, and human development have been implemented since the colonial period in sub-Saharan Africa. These strategies can be roughly classified into three approaches that today operate in parallel at different scales: Fortress conservation meant to separate people from wildlife by force and through displacement or resettlement. Initially an important intention was to protect humans and nonhumans from each other, while later the focus shifted towards attracting international tourism to advance national development and to protect globally valued biodiversity (Brockington 2002). Community-based conservation ${ }^{3}$ (CBC) evolved in parallel to fortress conservation since the 1980s to overcome the spatial separation of people and wildlife. CBC was driven by a dual objective of local development through obtaining economic benefits from wildlife conservation, and of wildlife protection outside of park boundaries. And finally, since the 1990s Landscape conservation rescaled conservation initiatives beyond spatial and institutional silos. Landscape conservation takes an ostensibly ecological approach to how people and wildlife should share space with each other across large geographical areas, crisscrossed by wildlife corridors to ensure protected area connectivity (Clay 2016; McCall 2016).

Today, the landscape approach is premised upon initiatives to sustain biological life itself. It dominates discourses and practices of land use and biodiversity conservation in Africa and beyond (DeFries, Sharma, and Dutta 2016; Sayer et al. 2016). In the last two decades, it has received growing attention and endorsement from different epistemic communities and academic disciplines, policy makers, donor agencies and conservation NGOs (Clay 2016; McCall 2016). In an interconnected and intertwined biopolitics of human and nonhuman species, both are to share a governable space that is valued for its high biodiversity. However, this space is not simply 'out there' to be discovered, but is conjured up by governmental and non-governmental conservation authorities and their donors in ways that are at least in theory expected to reconcile competing and at times conflicting land uses and interests towards the nurturing of human and nonhuman species' well-being. Conservation landscapes are thus underpinned by reconfigured biopolitical rationalities and rescaled geographies of conservation. In these new geographies of conservation, wildlife and rural people are jointly placed as objects of population management.

In this sense, landscape conservation interventions are biopolitical projects written on the land. A biopolitical inscription, more so than a developmentalist or a culturalist agenda, raises the stakes. It also depoliticizes and naturalizes conservation interventions. Life-sustaining landscapes of conservation are politically and emotionally supercharged with agendas, responsibility, meaning and purpose. When life itself is object of intervention and improvement, certain life forms must be protected (made live) while others can be abandoned (let die) (Biermann and Anderson 2017; Foucault 2003).

Taken at face value, the promise and rhetoric of conservation through a landscape approach suggests an unsettling of entrenched nature-culture divisions, moving towards new modes of living together. However, critical theorists have problematized the notion of landscapes in important ways. Landscapes invite an exclusive "way of seeing" (Cosgrove 1998) and valuing land, people and the environment through the lens of more powerful actors such as conservation NGOs, their donors, private investors and park authorities. References

${ }^{3}$ Also known as community-based natural resource management (CBNRM), or integrated conservation and development (ICDP). 
and claims to post-colonial landscapes are imbued with colonial-imperial legacies, uneven power relations and a power-laden politics of representation that involves classed, gendered and racialized images of a natureculture binary (Mitchell 2002; Rose 1993). Put differently, the promise of ecological and economic modernization through landscape conservation builds upon western hierarchies of power and knowledge, and it can hardly escape the colonial legacy of social control in post-colonial societies (Igoe 2017).

Under these conditions, the discourse of landscape conservation has the ability to transform areas of rural production into transnationalized spaces of biodiversity value (Igoe and Croucher 2007). Conservation biology's naturalization of the wildlife corridor logic produces a highly ecologized climate where other rationalities and research agendas become occluded (Goldman 2009). Attention to ecosystems at the landscape scale can produce new forms of exclusion, while expanding the purview of a green governmentality through conservation into lives and spaces previously ignored by conservation initiatives (Forsyth 2005). "Landscapism", or the rush to landscaping conservation initiatives, elevates conservation interventions into boundless claims to space (Wels 2015: 23). In sum, landscape conservation can reproduce pre-existing power relations, discredit local knowledge, marginalize local livelihoods, and above all it can authoritatively 'script' particular society-environment interactions in space through increased surveillance and policing (Clay 2016; McCall 2016).

In what follows, I demonstrate how landscape conservation and its biopower nurtures and protects certain life forms while demanding a biopolitical sacrifice from individuals or entire populations. I show how in this biopolitical drama, landscape conservation initiatives seek to entangle the fate of human and nonhuman species for the sake of national development through wildlife conservation. As a result, individual nonhuman lives are sacrificed in the form of trophy hunting, while alternative rural futures and possibilities become foreclosed for the human population. In the following sections I illustrate how the historical shift from fortress towards landscape conservation evolved in Tanzania (section 3), and how it dramatically changed perceptions about wildlife, rural people and what constitutes appropriate livelihoods in the study area (section 4). ${ }^{4}$

\section{A brief history of wildlife preservation and conservation in Tanganyika/Tanzania}

\section{Colonial rule through separation of people and wildlife}

Before the onset of colonial rule in 1885 in what was called German East Africa, Africans employed different techniques of wildlife and tsetse control. Lacking understanding of these techniques, and being interested in trophy hunting, the Germans established the first game and forest reserves to separate humans from wildlife. In the wake of catastrophic epidemics of the 1890s, human and livestock depopulation gave way to the collapse of local systems of ecological control. Human-wildlife interactions became unsettled, exposing human-controlled territories to a greater risk of crop raiding by wildlife and the spread of the disease-carrying tsetse fly (Kjekshus 1996). Most German reserves were confirmed and extended when the British administration took over the colony after World War I. Underpinned by biopolitically charged tropes of African primitiveness and backwardness, these colonial beginnings privileged white European settlers and hunters at the expense of black Africans who were deprived of access to wild meat. They lost some of their most fertile lands to reserves and more 'productive' European settlers (MacKenzie 1988). There were divisions in the British administration over how best to exploit and to govern its colonial territories in Tanganyika. Its main priorities were economic, yet colonial indirect rule had multiple and at times contradictory objectives. The effects of government and territorial control resulted in ambiguous and conflicting land and resource access laws (Iliffe 1979; MacKenzie 1988; Neumann 1998; Sunseri 2009):

\footnotetext{
${ }^{4}$ I draw on an extensive literature review, qualitative fieldwork in several villages around Tarangire National Park and on exchanges with Tanzania's conservation authorities in 2014-2017 (around 300 interviews overall). I also rely on a spatial analysis of historical and contemporary maps, GIS shapefiles, and aerial and satellite imagery. Detailed methodological description can be found in two related articles (Bluwstein 2017; Bluwstein et al. 2016) and my PhD dissertation (Bluwstein 2018).
} 
- To extract valuable resources

- To finance the colonial administration through taxation of the colonized

- To alienate fertile lands from Africans for European estates,

- To capture African labor for European landlords,

- To preserve African wildlife for the White hunt,

- To safeguard African farms against marauding wildlife,

- To increase African agricultural production for self-reliance and export,

- To grant customary rights to forest and game reserves to Africans, and to deny these rights.

These objectives were supported by a nature-culture dualism that the Western colonial regime imposed on its African subjects as part of its 'civilizing mission.' The British administrators launched country-wide tsetse-clearing and human resettlement campaigns to separate people from the increasingly tsetse-infested environment. They lacked awareness of African practices in containing, controlling and co-existing with tsetse by maintaining controlled contact to develop and maintain bovine resistance to it, and by actively shaping the environment through livestock grazing, fire and hunting, not by abandoning it to the fly (Adams and McShane 1992; Kjekshus 1996; Koponen 1988). The same western rationality of a nature-culture divide was applied to wildlife preservation and agriculture-based rural development. Both were, as clearly expressed by the Governor of Tanganyika, Mr. Cameron, to be treated as being "mutually exclusive" and conflicts were to be avoided through spatial separation. Cameron believed that "nowhere should game preservation be allowed to conflict with economic development. . . . If settlement and peasant cultivation are to extend in this territory, the preservation of game must depend on reserves, as the present wholesale or indiscriminate preservation of game is not compatible with agricultural development" (29.05.1929, PRO CO822/17/1, cited in Arlin 2011, my emphasis). While game was to be concentrated in reserves, people and their farms were to be organized in dense settlements (Neumann 2004a; Sunseri 2009). This was also expressed clearly in British colonial reports and journals, e.g. Hingston 1931: 406).

Relatively 'liberal' aspects pertaining to land and resource control remained in place throughout much of British colonial rule, because subsistence livelihoods were not seen as a threat to the environment (Neumann 1998: 100; Shetler 2007: 183). The 1921 Game Ordinance prohibited African hunting, yet it was hardly enforceable and was interpreted as not restricting access to game for subsistence (Shetler 2007). As late as 1928, British colonial officers seemed in "favour" of re-arming "all natives" in Tanganyika with firearms so that they could protect their farms against wildlife (Henfrey 1928: 118). If instituted, this initiative would have sacked the disarmament policy previously imposed under German rule. Nonetheless. The 1940 Game Ordinance granted access to wildlife protein, recognizing customary rights to residing and livestock grazing within game reserves and national parks. Concerns over crop protection from wildlife dominated much of Game Department's attention into the 1950s. Wildlife was labeled as pest, or vermin (especially elephants). The Game Department created some protected areas to separate and protect people and wildlife from each other, confining wildlife within reserve and park boundaries, while eradicating it outside (Garland 2006; MacKenzie 1988; Neumann 2004a). Despite a growing pressure from London's conservationist lobby from the 1930s onwards (MacKenzie 1988; Neumann 1998), colonial preoccupation with agriculture led to the introduction of an "agricultural bias" in school education in 1933 (Iliffe 1979: 339; also see Eckert 2007: 63-65).

After World War II, the colonial government's concerns with African land rights and peasant agriculture eroded, when Britain's demands on its colonies grew to support the war-ravaged economy at home. "Exportoriented development" through large-scale agricultural modernization became a governmental priority (Iliffe 1979: 470; Sundet 1997; URT 1994). Erosion of African land rights was furthered when the 1959 National Park Ordinance extinguished customary rights to residence and resource access within national parks. The postcolonial government extended this to forest reserves (Neumann 1998:120).

\section{National development through wildlife conservation}

The first President of independent Tanzania, Julius Nyerere, vowed to expand the state's protected areas. International conservation NGOs like IUCN and WWF lobbied Nyerere heavily, and were supported by influential conservationists like Bernhard Grzimek who fought against the establishment of land use-sharing 
arrangements for people and wildlife (Adams and McShane 1992; Neumann 1998). Despite his self-stated lack of interest in seeing wild animals, Nyerere placed his hopes on building tourism for economic development, declaring to be "entirely in favour of their survival. I believe that after diamonds and sisal, wild animals will provide Tanganyika with its greatest source of income." (Nyerere in 1961, quoted in Nash 1982). State authorities strategically invoked wildlife conservation as natural and global heritage to garner foreign financial assistance, to gain legitimacy in international diplomacy, and to build a sense of national identity and pride (Weiskopf 2015).

At the international conservation conference held in Arusha in 1961, a new biopolitical vision to govern both human and nonhuman species was formulated. This vision reflected a gradual shift from colonial preservationism for the exclusive pleasure of European 'sportsmen', towards utilitarian conservation through sustainable resource use to safeguard the survival of nonhuman species at the population level, for the benefit of people and wildlife (Adams 2004). Protected areas were to be extended "...to include the full habitat" based on scientific research, and rural people were to appreciate and economically benefit from conservation through education and awareness raising ("propaganda"), economic incentives, and effective protection of crops from wildlife raiding (IUCN 1963: 237). Put differently, a colonial biopolitics of governing people and wildlife by separating and thus protecting both from each other, began to shift towards the development of the new nation through the protection and nurturing of its wildlife resources. Through wildlife conservation and tourism, human and nonhuman population management would become positively intertwined.

Against the background of decolonization and post-colonial nation building towards socialist development, tourism was highly contested by student intellectuals, as the - by now forgotten - 'Tourism Debate' in 1970 vividly illustrated (Shivji 1975). Their critiques acknowledged that tourism "is something of a sacred cow", yet they rejected it as "cultural imperialism" that mainly benefits the "international bourgeoisie" and is incompatible with socialist Ujamaa ideology. The Ministry of Information and Tourism took part in the debate and responded that "tourism brings development" (Shivji 1975: ix, 1, 8, 75, my emphasis). Notwithstanding the radical critique, under the weight of an economic crisis and a growing international environmental movement in the 1970s, a conservation governmentality continued to unfold. The concept of biodiversity was introduced in the 1970s, channeling increasingly global concerns and promoting the creation of buffer zones around protected areas (Sunseri 2009). The Wildlife Conservation Act of 1974 was passed as the first major post-colonial legislation pertaining to wildlife management. A key purpose of this legislation was to facilitate revenue generation from trophy hunting, which was formalized across large areas and placed in the hands of central government as the sole owner of all wildlife in Tanzania (Leader-Williams 2000). Conservation through hunting inside protected areas (in game reserves) and on village land (in game controlled areas) represented a novel biopolitics of wildlife management at the population level. By sacrificing a relatively small number of individual animals as highly prized trophies, the entire wildlife population would be protected through revenue generation (Leader-Williams, Kayera, and Overton 1996).

The 1970s were also characterized by a shift in perceptions and priorities pertaining to relations between people and elephants (Figure 1). Until the early 1970s, elephants were frequently shot by game wardens as 'problem animals.' Biopolitical management of elephant populations for the protection of rural livelihoods was a fundamental colonial and early post-colonial policy. Prescribed elephant killings had begun in the early 1920s (around 500 elephants per year) and peaked in the 1960s when up to 3,700 elephants were shot annually (Leader-Williams 2000), constituting around 1\% of the Tanzanian elephant population at the time (MNRT 1994). After 1973, data on control of problem elephants became less readily available (Leader-Williams 2000, see Figure 1), indicating two shifts in priorities. First, a dramatic economic decline in the late 1970s and early 1980s led to the retreat of the state from protected area management, and ivory became desired as an illicit but lucrative income source for Tanzanians who struggled under economic hardship, including government employees (Garland 2006). This led to large-scale elephant poaching, which triggered new concerns for conservationists. Scientists introduced regular population monitoring and census campaigns to record the number of elephants (Neumann 2002). The handbook Counting animals by Mike Norton-Griffiths was first published in 1975, echoing this turn, and laying the foundation for the wildlife census campaigns that took off from 1990 (Figure 1). While organized poaching as a source of illicit income remained a common practice in many parts of Tanzania, elephants never regained their initial status as problem animals despite a growing 
human population. For instance, in 2009, when the human population had expanded threefold since 1970, and the elephant population diminished, only around 95 elephants were shot (Figure 1), amounting to less than $0.1 \%$ of the total population at the time (TAWIRI 2010).

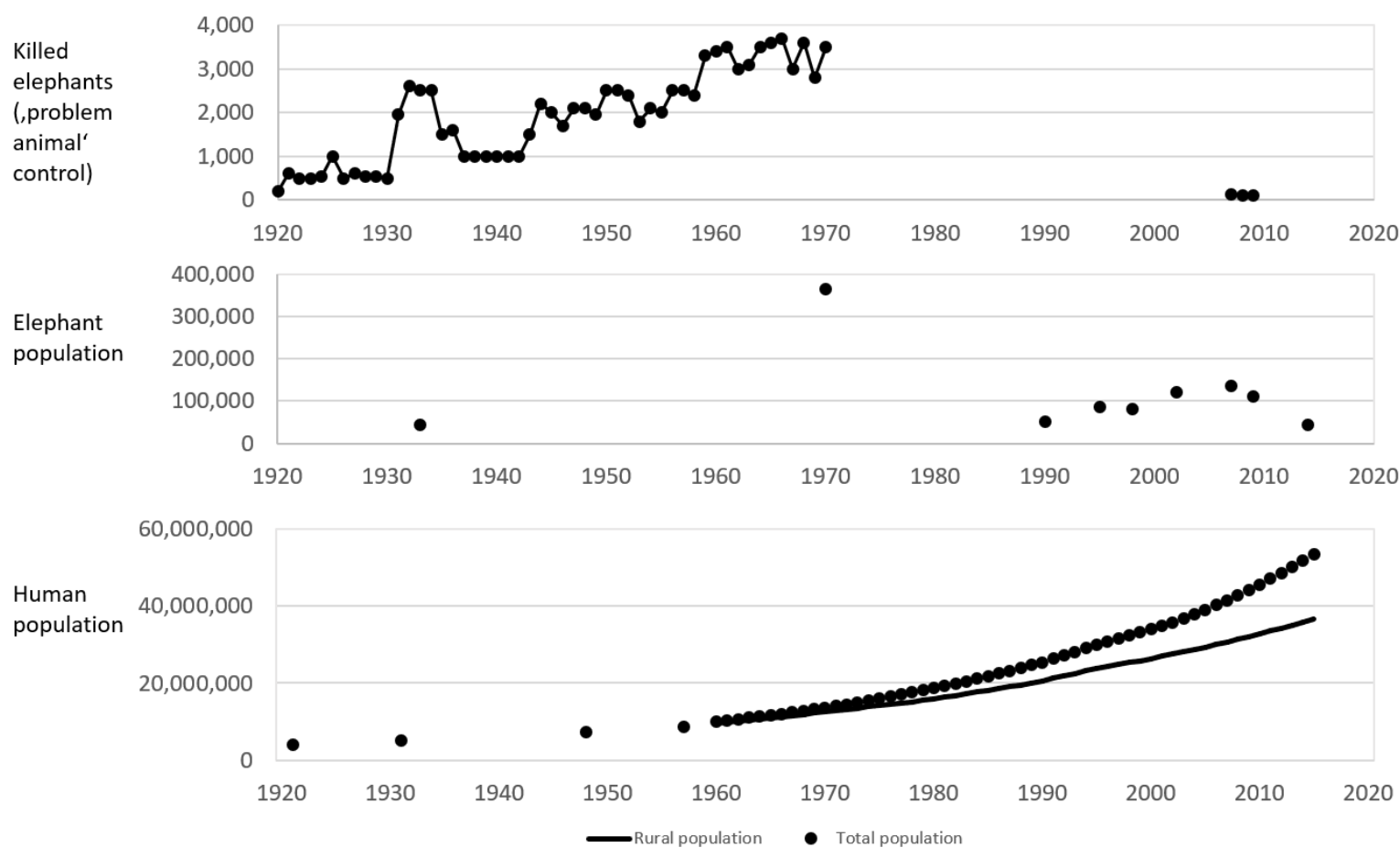

Figure 1: Shifting priorities, from problem animal control (until 1970s) towards counting animals (since the 1990s). Data sources: Leader-Williams (2000), TAWIRI (2010, 2014), MNRT (1994), Neumann (2001: 650, '1933' elephant population data point is averaged based on estimate of 3650,000 elephants), the World Bank, and Boesen et al. (1986).

These shifting biopolitical priorities dovetailed with a violent country-wide crackdown on illegal hunting in the 1989 Operation Uhai ('Life'). As its name suggests, this anti-poaching campaign echoed a growing biopolitical commitment towards a thriving elephant population. It involved the army and took place against the background of a 'new moral geography of violence' against rural people in the name of biodiversity (Neumann 2004b). This further shifted the asymmetry of how human and nonhuman lives were valued. Wild animals were increasingly anthropomorphized into charismatic species, while impoverished peasants were dehumanized into poachers, not simply subsistence hunters (Neumann 2004b: 813). Neumann (2004b) argues that the growing violence in the name of biodiversity protection since the $1980 \mathrm{~s}$ is historically unprecedented even in the light of colonial history. Coinciding with this development, the emphasis on training armed game wardens in wildlife control gave way to teaching them how to deal with rural people in order to protect wildlife from them (Adams and McShane 1992: 118; Garland 2006: 199).

\section{Neoliberalizing, expanding, and landscaping conservation}

The ongoing biopolitical shift towards the nurturing of nature was also reflected in the first experiments with community-based conservation (CBC) that were launched in the mid-1980s at the margins of protected areas to include people in wildlife conservation. USAID released significant funds in 1989 to launch a national wildlife policy reform dialogue and review, to create a more direct linkage between conservation and rural 
development through decentralization of resource control and benefit sharing. ${ }^{5}$ Big international conservation NGOs (BINGOs) such as AWF, WWF and WCS $^{6}$ became its principle implementers. Underpinned by the emergence of conservation biology as a biopolitical scientific discipline (Biermann and Mansfield 2014), ecology became an important power/knowledge regime inside and outside protected areas, structuring how nature should be understood and who the 'experts' were in charge of drawing distinctions between what is (not) natural, and where nature should begin and end (Luke 1995; Rutherford 2007). Attention to 'ecosystems', 'hotspots', 'biospheres', 'bioregions' and 'landscapes' led to the identification of numerous large-scale areas in Tanzania and around the world in need of conservation intervention (IUCN 1978; Myers 1988; Risser 1984; Sale 1985).

In this increasingly ecologized environment, rural peoples' subjectivities and their conduct outside of traditional protected areas (the conservation fortresses) were no longer ignored. Rather, they came into the direct purview of governmental techniques of proper management through education, disciplinary measures and incentives, when their attitudes and practices were perceived as environmentally harmful and incompatible with conservation (Bluwstein 2017; Holmes and Cavanagh 2016). Environmental and conservation education has arguably replaced the 'agricultural bias' in schools. Neoliberalization of conservation through new partnerships of state and non-state actors shifted the relationship between conservation and development decisively (Igoe and Brockington 2007). Although CBC predictably failed to deliver on the promises of people-centered conservation (Benjaminsen et al. 2013; Bluwstein, Moyo, and Kicheleri 2016), it had lasting effects in successfully introducing donor and NGO attention and funding beyond core protected areas. With this momentum, community-based conservation interventions and core protected areas were reconfigured and rescaled into conservation at the landscape/ecosystem level (Hurst 2004).

The paradigm of landscape conservation and ecosystem science entered the body of law through the Wildlife Conservation Act of 2009. Here, it was stipulated for the first time that the Ministry of Natural Resources and Tourism can "designate wildlife corridors, dispersal areas, buffer zones and migratory routes" on legally recognized village land. Concretely, the Act suggests that communities' rights to village land would be recognized conditional on being "compatible with conservation" if the land overlaps with wildlife corridors (URT 2009: §22, my emphasis). In other words, this new legislation challenges Tanzanian land laws that place village land in the politico-administrative hands of elected village councils.

Today, we have reached a critical biopolitical conjuncture, in which human presence around Tanzania's protected areas is perceived as invasive and unnatural, and as a threat to conservation. In 2009, an influential Tanzania-wide study by leading conservationists raised alarm by suggesting that "the majority of documented [wildlife] corridors in the country now seem to be in critical condition." Agricultural expansion and lack of land use planning were blamed for the situation, and the "sustainability of the tourist industry" was put in question (Jones, Caro, and Devenport 2009: 4). This report fed into the national Elephant Management Plan 2010-2015 that - contrary to the 1994 recommendations - avoided setting upper national limits for the elephant population. The "carrying capacity of [elephant] ecosystems" had not yet been reached according to the report (TAWIRI 2010: 4). However, human settlements, livestock grazing areas and farms were not taken into account in this estimate, thereby being rendered as unnatural to ecosystems. Following a similar "natural habitats" logic, a recent continent-wide elephant population model produced an "ecological benchmark" for elephant populations by erasing human populations from the "ecological context" across sub-Saharan Africa (Robson et al. 2017: 12). The authors calculated that, for instance, Tarangire National Park in Northern Tanzania should have an ecological benchmark density of around 3.25-3.75 elephants $/ \mathrm{km}^{2}$, implying that the park with its current density of 1.2 elephants $/ \mathrm{km}^{2}$ is significantly underpopulated due to human activities. Modelling away and thereby erasing the human dimension in calculating an unprecedented number of elephants that Tarangire should have today, is a quintessential biopolitical act. It is 'letting die' rural people who are already vulnerable to elephant crop damage and loss of life. In the following section I turn to Tarangire National Park to explain how an area formerly considered as agricultural came to be understood as a timeless, boundless and threatened natural elephant habitat.

\footnotetext{
${ }^{5}$ Planning and Assessment for Wildlife Management (PAWM).

${ }^{6}$ African Wildlife Foundation, World Wildlife Fund, Wildlife Conservation Society.
} 


\section{The evolution of Tarangire: from isolation and containment towards an expanding landscape}

Today, Tarangire National Park is part of the so-called Tarangire-Manyara Ecosystem (TME), an international donor and conservation NGO-supported mosaic of two national parks, a game reserve, and various community-based conservation initiatives on village land (Figures 2 and 3). ${ }^{7}$ This conservation landscape is supposed to secure an uninterrupted and unconstrained wildlife migration across the entire TME, spanning 3 regions, 5-7 districts, around 80-100 villages and 300,000-400,000 people ${ }^{8}$, who self-identify as Maasai, Warusha, Rangi, Barabaig, Mbugwe, and many more. To secure wildlife mobility and protected area connectivity across the TME, wildlife dispersal areas on village land are to be protected from being blocked by human settlements, agriculture and livestock 'overgrazing.' Indeed, Tarangire's wildlife depends more on village land than on land enclosed by protected areas, spending a lot of time outside park boundaries during the wet season, roaming through village lands. In the past decades these lands have been increasingly converted to agriculture by small-scale and subsistence users, and also by large-scale commercial and speculative investments (Msoffe et al. 2011).

In conversations with Tarangire park authorities and conservation NGOs it is obvious that their primary concern is not with what happens within the park. Rather, the increasing isolation of Tarangire's wildlife migratory routes by agro-pastoral land use around the park is considered the biggest threat to the national park, the Tarangire River as the main water source for wildlife, and with it the entire TME landscape. These concerns are prominently placed within the national press:

"If the trend continues with no efforts to control human activities and population increase, we may end up having no Tarangire Park in [the] future," [Tarangire Chief Park Warden] says. . . . The communities, mostly the Maasai pastoralists and farmers, living around the park [are] the main people imposing the threats. (Robi 2016)

[T]he entire Tarangire-Manyara ecosystem faces a massive decline in wildlife populations due to an increase in human population coupled with an ever increasing demand for land uses not compatible with conservation interests. (Ihucha 2014, my emphasis)

In such a seemingly apocalyptic atmosphere, agro-pastoral livelihoods are perceived to be a dangerous life form that needs intervention to align it with contemporary landscape conservation governmentality. Today, Tarangire's wildlife population is thus managed indirectly by intervening in human populations. This biopolitics aims to make human activities - rural livelihoods - compatible with wildlife conservation objectives. Yet, looking back at the origins of Tarangire as a wildlife refuge, present concerns over the isolation of Tarangire through human activities are at odds with the initial intention to create Tarangire as an isolated wildlife container to control wildlife populations for the sake of rural development.

\footnotetext{
${ }^{7}$ Village land is a legal category designating land under administrative control by elected village councils.

${ }^{8}$ Since the boundaries of TME are not fixed, there is plenty of room for interpretation of different claims as to what territories are part of TME. My estimate only includes villages that directly border protected areas within TME and is based on the official population census of 2002 and a projection of population growth until 2017 (3\% annually). Since 2002 many new villages were created by splitting old ones.
} 


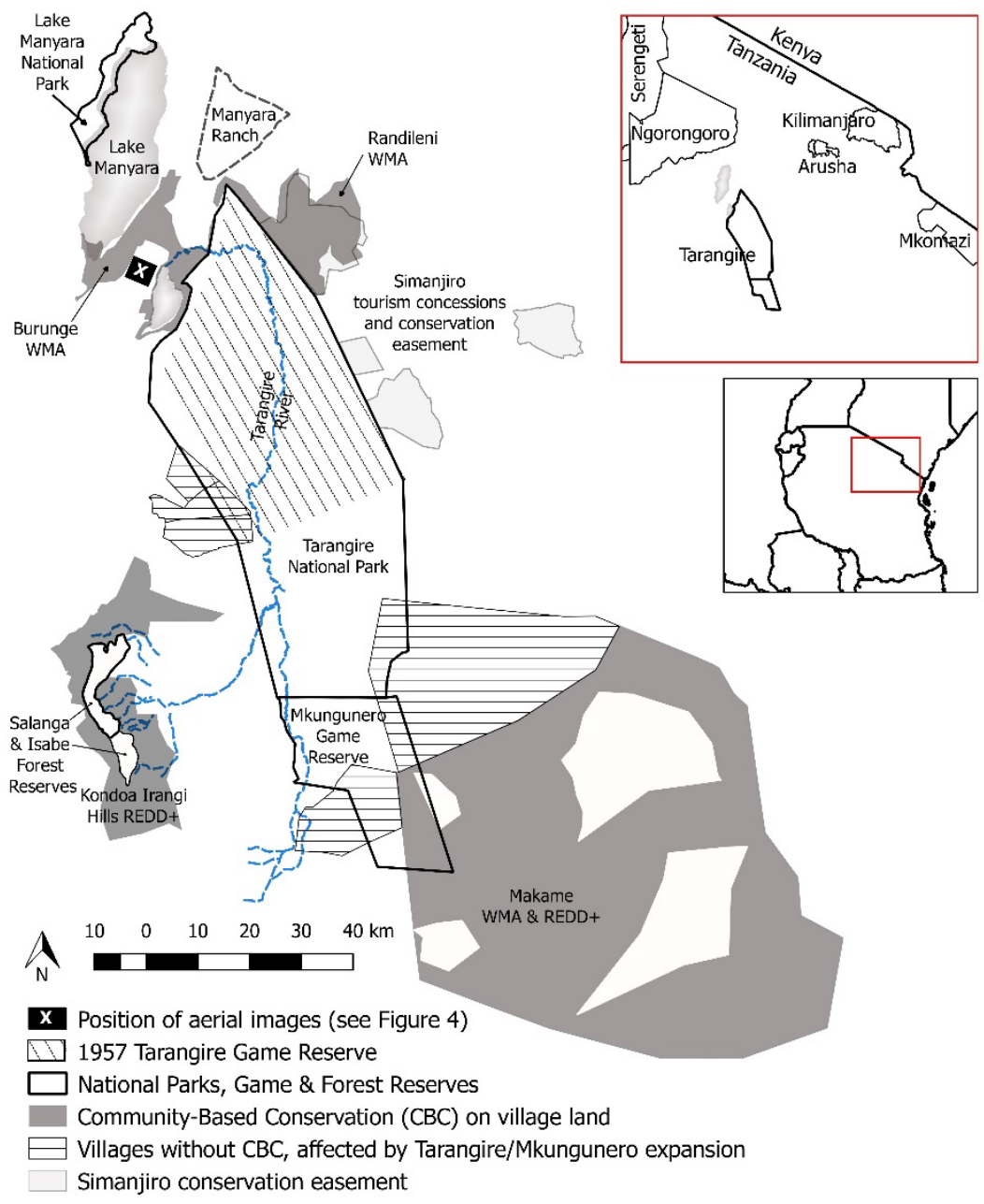

Figure 2: Tarangire-Manyara Ecosystem in Northern Tanzania. Source: author.

\section{From an enclosed conservation island...}

In the 1930s colonial administrators in Tanganyika started debating the possibility of establishing protected areas in present day National Parks of Tarangire and Lake Manyara (Figure 2). In 1935 the governor rejected a suggestion to create a national park on the western shore of Lake Manyara, seeing it as being part of "one of the richest agricultural areas in the Territory" (Kjekshus 1996: 76, citing TNA 11234, II). Then again, a game warden suggested in 1949, believing that the area around Tarangire River was not populated and hardly used, that "[i]t is most desirable to have a National Park in an area where the interests of man and game do not clash" (ACC 69 275/1 Vol.1, cited in Arlin 2011). Such a position was not shared by many colonial bureaucrats who became weary of the proliferation of game reserves in the region and the role of European hunters. A District Commissioner, by his own account "a game lover", expressed his conditional support for a Tarangire Game Reserve, if the Game Department would "surrender land elsewhere" in exchange (DC Masai Monduli, 22/06/1949, in ACC69 275/1 Vol.1, cited in Arlin 2011). Importantly, proponents of Tarangire being an agricultural area dominated the debate until 1955 (Arlin 2011). Eventually the Game Department prevailed. Tarangire and Lake Manyara Game Reserves were gazetted in 1957. Wildlife would be contained within both reserves where it could be hunted by Western tourists. 


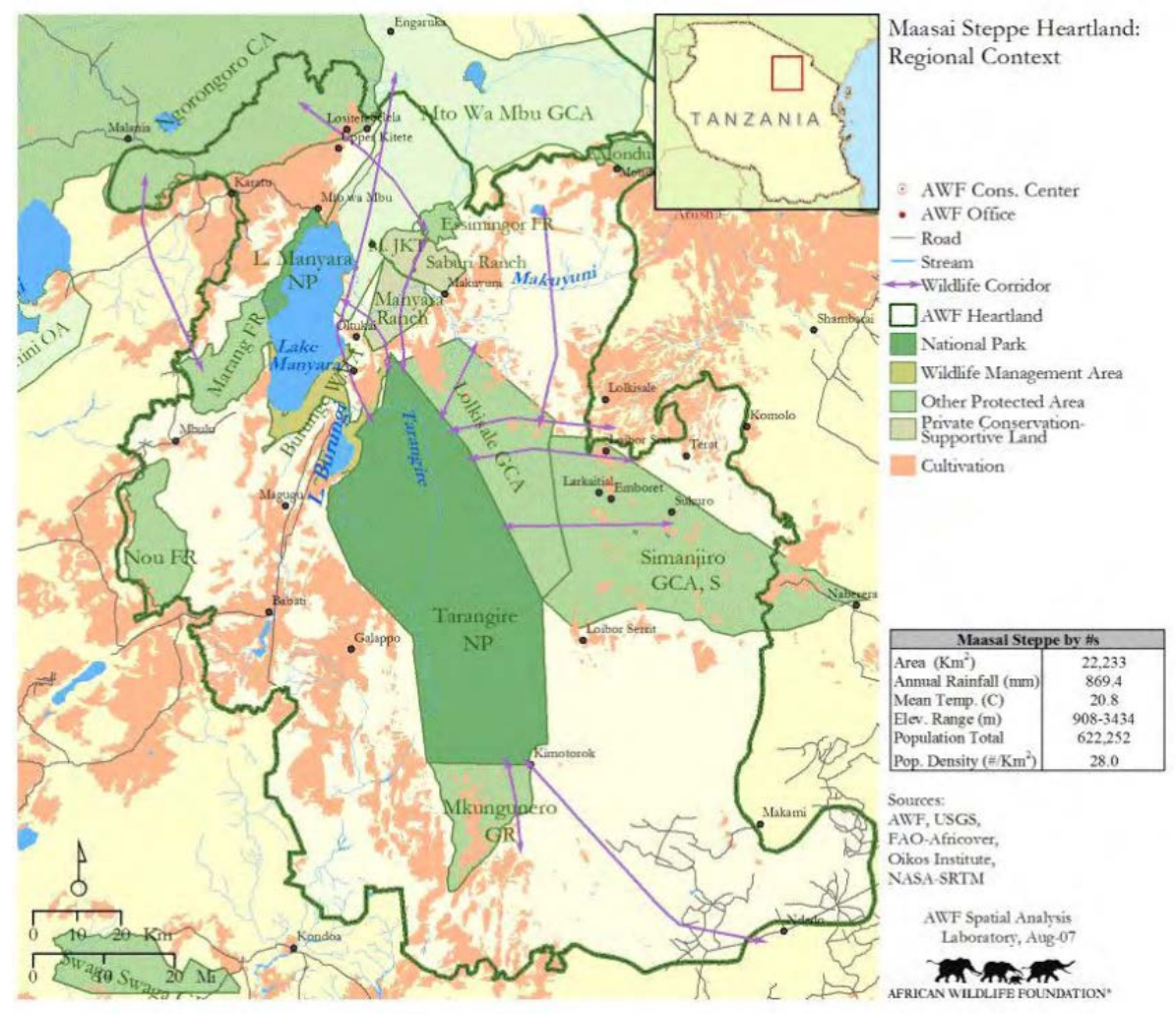

Figure 3: Tarangire-Manyara Ecosystem, also known as AWF's Maasai Steppe Heartland. Source: Sachedina (2008).

While colonial administrators argued over what government priority should be, there was a consensus that human and nonhuman interests were unrelated and irreconcilable. Indeed, as Tarangire was officially gazetted, parts of the area situated between Tarangire and Lake Manyara were intensively farmed, as aerial photographs illustrate in Figure 4. In the following years, more people were encouraged to settle and cultivate there, while hunters were allowed to shoot game in the same area. Ironically, decades later and still today local people would be framed as "invaders" encroaching on allegedly "ancient" wildlife migration corridors, and some would be forcefully removed to make space for wildlife (Bluwstein 2017; Xinhua 2017).

In 1957 a British biologist, Hugh F. Lamprey, was stationed in Tarangire. Lamprey has been the first wildlife biologist to work in East Africa, since 1952. He spearheaded a new era of scientific wildlife management that was introduced by colonial powers and the United States in the 1950s (Neumann 2002). In the coming years, Lamprey systematically studied wildlife movements and documented seasonal migratory routes inside Tarangire Game Reserve and beyond (Figure 5). His research would later contribute to the inversion of the initial idea of Tarangire as a wildlife container. A new vision of Tarangire was in the making, rendering it the core of a much larger area, traversed by wildlife hundreds of kilometers beyond the reserve's boundaries in search of pasture and water (Lamprey 1964). In 1970, Tarangire was upgraded to a national park and its southern boundary significantly extended (see Figure 2). To the later Prime Minister Edward M. Sokoine this upgrade meant for the Maasai "the loss of homes, grazing pastures and water points that they urgently needed for themselves and their cattle" (Hagen 1979: 7, my translation from German). The expansion from a game reserve to a national park advanced a post-colonial governmentality of nation building through photographic tourism-based development. Tarangire was now, jointly with Lake Manyara (upgraded from a game reserve to a national park in 1961), able to attract photographic tourism in support of state efforts to capture desperately needed foreign exchange. 


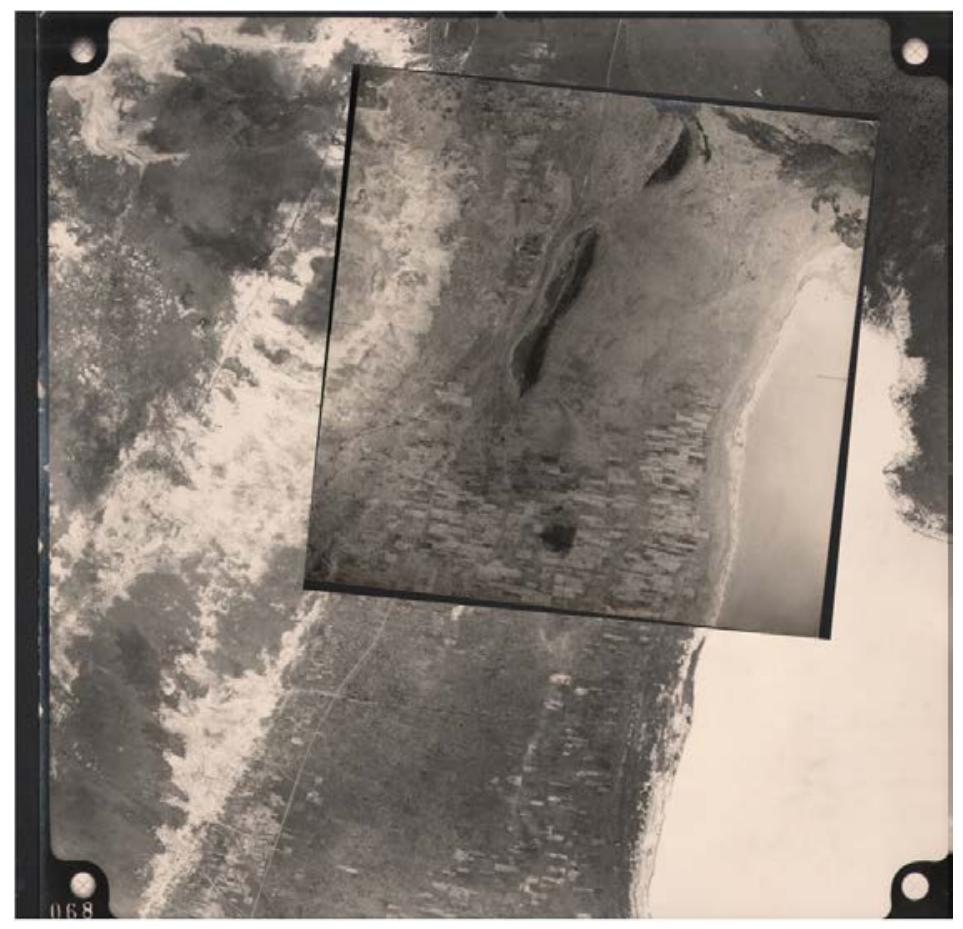

Figure 4: Aerial photographs of farms between Tarangire and Lake Manyara (see Figure 2 for geographical context). Small photograph taken between 1950-54 (exact date unknown, sheet 69, run 1098, exposure 2). Big photograph taken on 20/02/1958 (sheet 69, run 35TN7, exposure 68). Courtesy of Ministry of Lands, Dar es Salaam.

\section{...towards an expanding conservation landscape}

Tarangire received little attention by the state when it retreated from wildlife conservation during the period of dramatic economic decline in the late 1970s to early 1980s. In 1985, coinciding with a shift from state socialism towards the neoliberalization of Tanzania's economy, Markus Borner from the German NGO Frankfurt Zoological Society published an influential article in an international conservation journal (Borner 1985). Borner revisited Lamprey's study and concluded that Tarangire is "increasingly isolated" by agricultural expansion, which was precisely what colonial creators had in mind when Tarangire was created. Borner made concrete recommendations to prevent the isolation of Tarangire as an island. He recommended putting areas south and east of Tarangire (Figure 6, center) under a "new land-use authority" and to create a wildlife corridor free from agriculture between Tarangire and Lake Manyara (Borner 1985: 95). Pastoralism was to be controlled by conservation authorities through "cattle quotas and grazing management" (Borner 1985: 94). In this way, the alleged "over-use and deterioration of livestock pastures", and soil "erosion" and "degradation" could be contained (Borner 1985: 94). Echoing colonial paternalism, Borner suggested that this "unpopular" move "would ultimately benefit the Maasai" (Borner 1985: 96). Importantly, Borner justified his recommendations in economic terms, arguing that wildlife "must be preserved if the tourism value of Tanzania is to be maintained" (Borner 1985: 96). Repeated efforts by Tarangire park authorities and conservation NGOs to implement Borner's recommendations east of Tarangire in the 1980s and 1990s have proven to be unsuccessful due to local resistance by Maasai leaders, and a Maasai NGO that recognized the looming threat of land alienation and food insecurity in the name of conservation (Igoe and Brockington 1999; Sachedina 2008). 


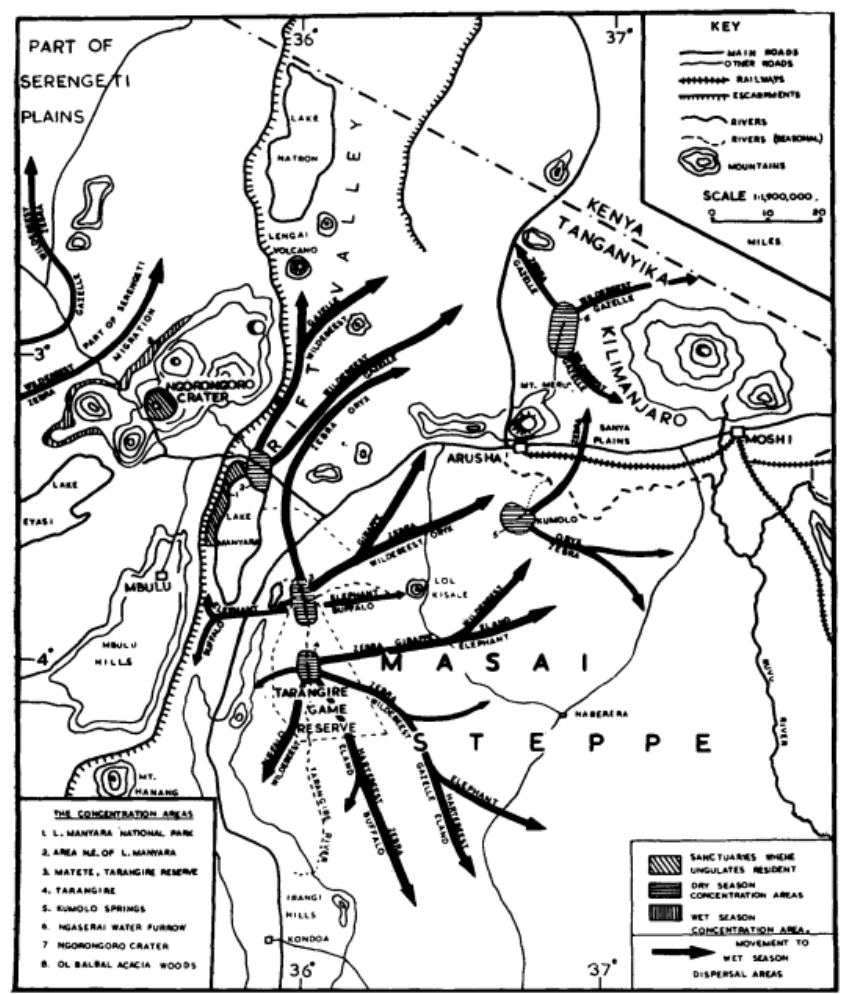

principal game concentration areas a rain-season dispersal routes

THE MASA I AREA, TANGANYIKA

Figure 10
Map of the Masai Area of Tanganyika to show the status of the Tarangire Game Reserve as a dry season concentration area. The arrows show the approximate routes
followed by dispersing animals when they leave the Tarangire Reserve and other concentration areas at the beginning of the rains each year.

Figure 5: Wildlife dispersal routes according to Lamprey (1964). Tarangire Game Reserve is mapped left of 'Masai Steppe.'
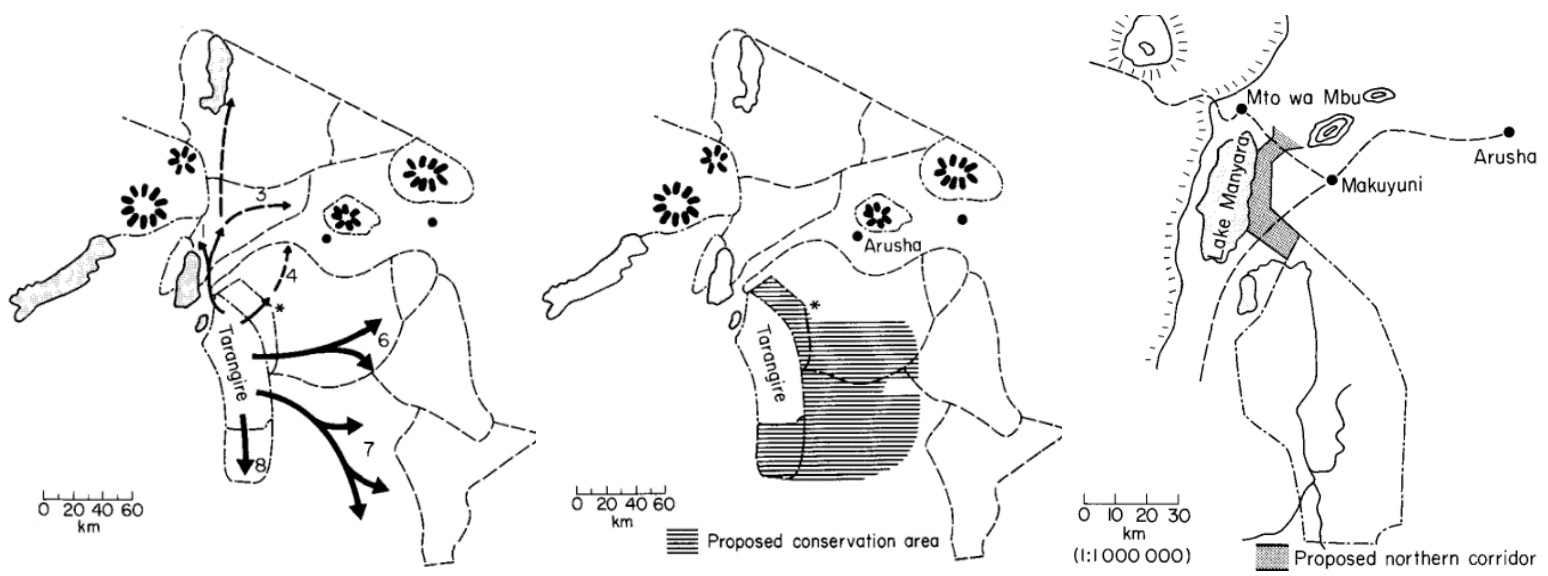

Figure 6: Borner's mapping of wildlife dispersal routes (left), proposed conservation area expansion (center) and proposed wildlife corridor (right). Source: Borner (1985). 
Over the next few years, two additional research articles proposed concrete interventions to prevent the perceived isolation of Tarangire and Lake Manyara National Parks. The Tanzanian researcher R. Mwalyosi suggested the establishment of a wildlife corridor in combination with a buffer zone and incentives for rural people to change their land use (Mwalyosi 1991). The Dutch conservation biologist H. Prins recommended prohibiting human settlements between Tarangire and Lake Manyara National Parks (Prins 1987), effectively calling for a large-scale resettlement of entire villages. Judged by the 1988 human population census (Mwalyosi 1991), tens of thousands of people would have been affected by Prins's vision of a deeply authoritarian green governmentality (Figure 7).
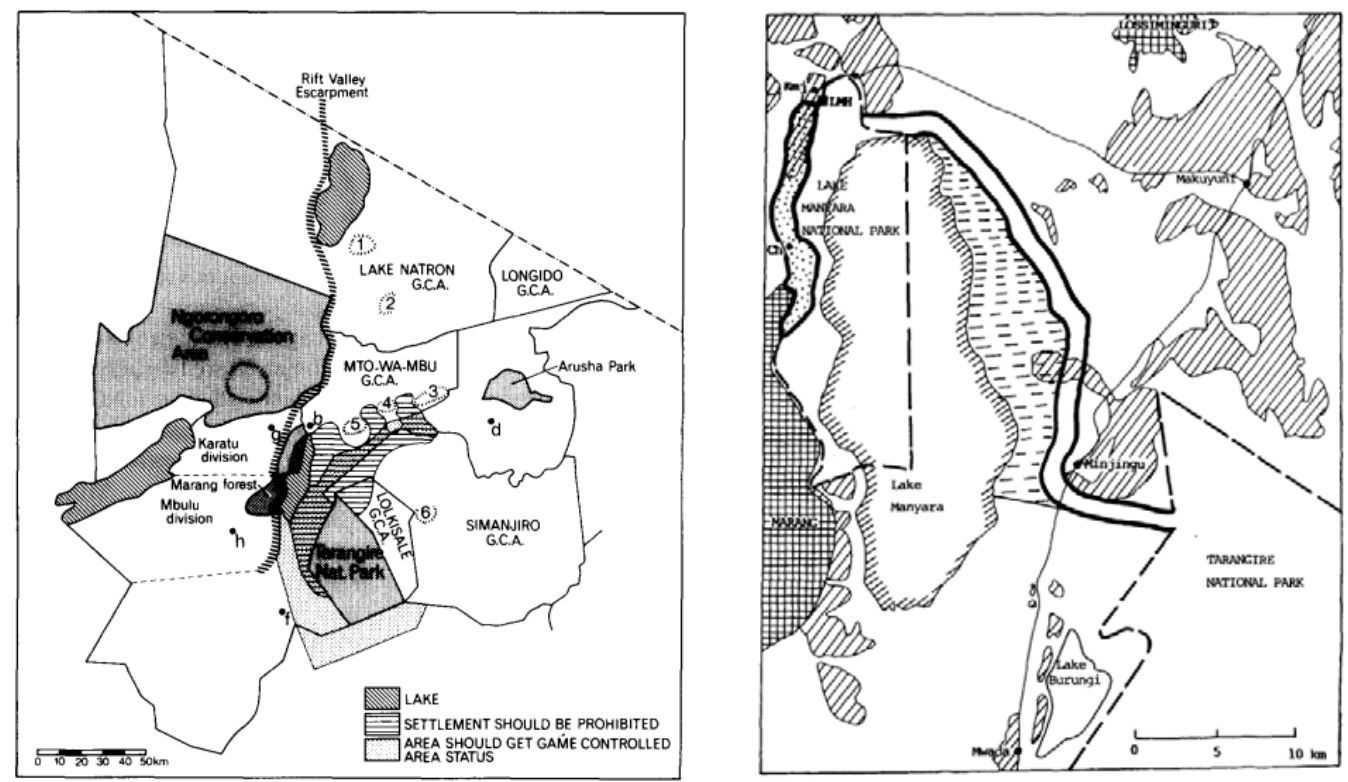

Figure 7: Left map: 'recommendation to prohibit human settlements between Lake Manyara and Tarangire National Parks.' Source: Prins (1987). ${ }^{9}$ Right map: 'proposed game corridor and buffer zone.' Source: Mwalyosi (1991).

In response to these growing concerns over the fate of Tarangire's wildlife, Tarangire park authorities launched the Community Conservation Services unit in early 1990s to improve park-community relations with adjacent villages through the so-called 'Good Neighbourliness' program. Since the park establishment, many residents perceived it to be encroaching gradually on their villages, in part due to widely shared uncertainties about park boundaries. Land conversion to agriculture was one of the local responses to stop this encroachment (Sachedina and Nelson 2010). This development was problematized in the 1994 National Park Policy that declared that without "the practice of compatible land use practices around parks", the mandate to protect national parks cannot be fulfilled (TANAPA 1994: 2, my emphasis). Given that park authorities were not willing to allow rural people to use park resources, nor were they willing to compensate rural people for costs incurred by the park, community outreach was ultimately deployed as a disciplinary technique to govern people by intervening in rural subjectivities, obscuring the "true costs" of wildlife conservation. The strategy was to "manage expectations" of rural people by keeping these as low as possible without promising substantial revenues or meaningful participation in decision-making for wildlife conservation or land control (Bergin 2001: 102). Indeed, an internal report from 2007 concluded that merely $1.8 \%$ of earned revenue from Tanzania's National Parks was reinvested in community services, although wildlife uses communal lands extensively (TNRF 2008).

\footnotetext{
${ }^{9}$ Notice how the author wrongfully maps Tarangire National Park in its pre-1970 Game Reserve boundaries.
} 
Meanwhile, some private safari tour operators, NGOs and village governments started to experiment with a pioneering model of neoliberal conservation, agreeing to overcome a strict separation of people, their livestock and wildlife towards a shared space. The actors negotiated concession agreements with villages east of Tarangire in 1990 in the so-called Simanjiro plains (see Figure 2), the same area that Markus Borner recommended for a strict conservation-based land use regime. Contrary to Borner's coercive conservation approach, villages were offered money in return for mutually negotiated agreements over conservation easements, stipulating that village land would not be converted to agriculture, but would in some cases host photographic tourism (Sachedina and Nelson 2010). Tour operators aimed to benefit from safeguarding viable wildlife populations that would move out from Tarangire during the wet season, while village governments would benefit from new income revenues while securing access to their land for livestock grazing. The only condition was to prevent cultivation and an influx of in-migrants, through community-based policing.

In 1993, the elephant researcher Charles Foley launched the Tarangire Elephant Project with funding from the NGO WCS. Today, it is promoted as the longest ongoing elephant research project in the world. In 1995, the Italian-led University/NGO-run Tarangire Conservation Project (TCP) launched a conservation biology and land use research program within and outside Tarangire. TCP produced vegetation and land use maps, and detailed wildlife demographic and spatial data. These research outputs and park authorities' early experiences with community outreach fed into a multi-stakeholder planning workshop in 1998. The workshop revolved around the importance of village land use planning as a mechanism to identify and safeguard wildlife migratory routes, corridors, and dispersal areas outside of park boundaries. Representatives from district government, NGOs and the private sector concluded that local communities may be affected negatively by conservation interventions on village land due to an anticipated lack of benefits and the risk of land alienation, rising land conflicts, increasing wildlife crop raiding and possible loss of human life. To balance some of these anticipated negative outcomes, NGO and private sector representatives recommended at the workshop that people should be allowed to graze their livestock within Tarangire and Lake Manyara National Parks during the dry season (TANAPA 1998). Instead of implementing this recommendation, in the coming years the consolidation of the landscape vision of Tarangire animated a series of interventions to alter the conduct of rural people to align it with a conservation territoriality, in which human land use is spatially and temporally bounded and fixed so that wildlife can roam free beyond protected areas across the entire conservation landscape.

\section{Consolidating the landscape}

A landscape conservation territoriality was jointly produced by conservation authorities and charismatic wildlife species. Radio-collared elephants and lions enabled conservation biologists to track wildlife movements and home ranges. A GIS center was established in Tarangire National Park to produce land use and land cover maps, and park authorities were better equipped to carry out anti-poaching patrols and boundary protection. These activities further consolidated Tarangire as a center of a wider conservation landscape, allowing conservation authorities to extend territorial claims into areas of rural livelihoods, and to intervene in rural land use practices and subjectivities. In particular, the NGO African Wildlife Foundation (AWF) spearheaded a landscape vision for Tarangire. AWF skillfully exploited the global public outcry over widespread elephant poaching in 1989 by joining the global ivory trade ban campaign. This significantly increased its membership and funding (Bonner 1994). From 1989, AWF was funded generously by USAID. USAID's engagement was underpinned by a novel biopolitical vision to "improve the quality of life in Tanzania" by encouraging appropriate "conservation behavior" through "economic and other livelihoods incentives." Against the colonial origins of conservation, USAID's underlying premise was that "human development is compatible with biodiversity conservation" (USAID 2004: 71ff, my emphasis). AWF created a branding campaign to attract North-American funding by framing large swathes of African lands as "Heartlands" in the late 1990s (Sachedina 2008). Tarangire became the center of the "Maasai-Steppe Heartland" (Figure 3). AWF's declared objective was to conserve "landscapes of exceptional biodiversity value", and "to conserve viable populations of African wildlife as well as key habitats and ecological systems well into the future" (AWF n.d.-a). AWF had big ambitions in and around Tarangire: "...if we are to be successful in conserving natural resources in the long run, then we have to work outside of protected areas and involve all the players. We can't just limit our work to the [Tarangire] park. . . . [The project] has the potential to completely 
change the way the world looks at ecosystem management" (AWF 1998). To realize this vision, AWF framed its approach as "threats-based conservation at a landscape scale" and identified "subsistence agriculture, unplanned settlements, and inadequate land use" as the main threats to Maasai Steppe Heartland and the "the ecological viability of landscapes" (AWF n.d.-b).

This governmentality produced new forms of human inclusion and exclusion. While some groups were tolerated within the conservation landscape under certain conditions, others were to be excluded from the landscape altogether. For instance, AWF envisioned that pastoralists living around Tarangire would be "sensitized" to "counter inappropriate immigration and agricultural development." The goal was to encourage "'conservation compatible livelihood diversification"' in form of "'wildlife or biodiversity enterprises"' under a strict land use planning regime (GEF 2003: 21). The conjured landscape of donor and NGO intervention was meant to lead to the creation of a tourist destination through the production of spectacular images that would convey a sense of an ahistorical, primordial and unmodified space for wildlife (Igoe 2017).

With AWF's facilitation, around 60 people living in officially recognized villages between Tarangire and Lake Manyara were resettled in the mid 1990s to free up an assumed wildlife corridor from human settlements (Igoe and Croucher 2007). The corridor project largely echoed Borner's and Mwalyosi's proposals (Figure 6, right map; Figure 7, right map). Thereafter, AWF spearheaded the implementation of Burunge Wildlife Management Area (WMA) in this location. Several villages were promised economic benefits from WMA membership in return for setting aside a share of village land for wildlife conservation. Those who refused to join the WMA were coerced through dubious tactics and manipulation (Igoe and Croucher 2007). A joint WMA land use plan was implemented to separate people from wildlife on village land and to create the cultivation- and settlement-free wildlife corridor. Burunge hired around 30 village game scouts from its villages to police rule-breaking by residents on their own village land (Bluwstein, Moyo, and Kicheleri 2016). An expatriate investor was allowed to establish an exclusive large-scale wilderness tourism regime in Burunge with almost no access to dry-season livestock grazing. The investor promotes a vision of an ancient, threatened elephant landscape, ignoring an extensive history of agro-pastoral land use. The investor hired a paramilitary force of more than 50 guards to secure large parts of village land against local use (Bluwstein 2017). Complementary to the establishment of Burunge, AWF also launched Randileni Wildlife Management Area in close proximity to Burunge to ensure wildlife connectivity between Tarangire and Lake Manyara (Figure 2). Similar to experiences in Burunge, people living in Randileni had little say in land use planning and decisionmaking (Loveless 2014). Running counter to colonial rationality, conservation biologists today consider villagebased interventions (such as WMAs) to be successful if they can reduce the livestock density in the villages while increasing the presence of wildlife on village land (Lee and Bond 2018).

East of Tarangire National Park, AWF raised alarm about "an imminent threat to tourism revenues" from agricultural land use. In reviving Borner's ideas, AWF backed a "moratorium on land allocations to agriculture" that risked undermining local food security (Sachedina 2011: 148). North of Tarangire, an AWF-backed land trust took over a former state-run cattle ranch in the early 2000s. The so-called Manyara Ranch (see Figure 2) serves as a grazing area for Maasai living in adjacent villages and is - in addition to Burunge and Randileni WMAs - perceived to be an essential part of a wildlife corridor between Tarangire and Lake Manyara National Parks (Goldman 2009). Through deception, local Maasai communities signed off on a deal that would undermine their land claims and grant management rights to the land trust (Davis and Goldman 2017).

In 2004, Tarangire authorities re-surveyed park boundaries for the first time since park establishment, using GIS technology introduced by an NGO. They concluded that the national park is not 2,600 $\mathrm{km}^{2}$ big as assumed until then, but $2,850 \mathrm{~km}^{2}$. In response, hundreds of households were forced to give up cultivation and housing on officially recognized, demarcated, settled and farmed village land across three villages west of Tarangire (Boerstra 2017, see also Figure 2). Similarly, south-east of Tarangire, Maasai residents from Kimotorok village were told to move out of the village center in 2005 when it was claimed by the park after the boundary re-survey (Figure 2). Park authorities claimed a "heavily populated area with considerable human activity" (Masara 2005: 12).

Kimotorok residents were also affected by a boundary re-survey of another protected area - Mkungunero Game Reserve - in 2006. Until then, the reserve largely existed on paper only, and was home to permanent and 
temporary settlements, farms and livestock grazing. ${ }^{10}$ Mkungunero was initially established as a game reserve in 1996 without consent from resident Maasai agro-pastoralists or Rangi farmers, and without resources to enforce its boundaries. Yet it was believed to harbor a corridor for Tarangire's wildlife and echoed Borner's recommendation (see Figure 6, left map, wildlife corridor \#8, and center map). The reserve and its wildlife were to be protected by keeping the area free from human activities and by encouraging trophy hunting to generate revenues for conservation. According to Sachedina (2011), AWF encouraged evictions from Mkungunero by withholding funds that the NGO raised for the game reserve, but would not distribute unless the reserve was freed from its residents. After Mkungunero was resurveyed in 2006, residents killed two game wardens in a dispute over reserve boundary demarcation. Violent attempts to evict people escalated in 2013, when conservation authorities jointly with the military and special police forces tried to evict Kimotorok Maasai from Mkungunero and from the south-eastern margins of Tarangire within the scope of the national military-led Operation Tokomeza Ujangili ('Eradicate poaching'). Echoing the 1989 Operation Uhai ('Life'), Tokomeza espoused a biopolitical commitment to a thriving elephant population. ${ }^{11}$ Tokomeza's violence south-east of Tarangire was documented by the Manyara Regional Police Commander who summarized in a letter to the Regional Commissioner the actions committed against Kimotorok residents in September 2013: 8 arrested residents, 11 burned homesteads housing several hundred people, stolen or burned cash and livestock, poisoned stock of food, and a raped woman. ${ }^{12}$

Despite the Tokomeza incident, the director of Mkungunero Game Reserve expressed no sympathy for people whose land is claimed by conservation authorities. He maintained that "by not conserving Mkungunero you kill the Tarangire River and the Tarangire National Park" (Interview 2015). The idea that Tarangire River's headwaters are threatened by human activities was reinforced in 2010 after AWF launched the Kondoa Irangi Hills REDD+ project west of Tarangire (Figure 2). ${ }^{13}$ The now-failed and abandoned REDD+ project aimed to protect the Tarangire River by intervening in local land and forest use practices across 21 villages and two forest reserves (Svarstad and Benjaminsen 2017).

In 2014, USAID chose not to extend its long-standing financial support for AWF. A USAIDcommissioned evaluation of AWF activities in Northern Tanzania offered a picture of "considerable 'work-inprogress' difficulties", "disgruntled communities" and a range of challenges, as summarized in a USAID report:

Landscape conservation is a sound concept, but it introduces the problems of effectively managing a very complex set of activities. ... Highly nuanced trade-offs between goals and strategies, like water used for crop irrigation not reaching the ecologically vital Tarangire River, higher wildlife-caused human fatalities, increased elephant destruction, and more predator raids, also complicate matters. There are no easy answers to such conundrums. (USAID 2014: vi)

USAID staff were frustrated with AWF's approach, since it created so much hostility in the villages. Yet, problems, challenges and even outright failures in achieving conservation objectives only serve to legitimize continuous interventions (Bluwstein and Lund 2018). In 2015 USAID awarded a five-year multi-million US\$ grant to a new NGO consortium with the title Northern Tanzania Rangelands Initiative (NTRI). NTRI also embraces a landscape conservation vision and targets an area that overlaps with AWF's initiatives. NTRI sees this landscape "at risk" due to "human population growth, competing land use interests, resource limitations, insecure land and resource rights." NTRI's objectives are to "restore balance" between people and wildlife and

\footnotetext{
10 The game reserve authorities mapped the extent of farms in Mkungunero, amounting to around 10\% of the reserve area (date of map unknown). Using Google Earth satellite imagery, I estimated an aggregated $21 \%$ of the reserve was under cultivation between 2010 and 2016.

11 The operation was launched across the country in response to the elephant poaching crisis in southern and western Tanzania of late 2000s/early 2010s. Across Tanzania, several people were killed extra-judicially by forces that included police, conservation paramilitary units and the army. One of the victims was a wife of a "poaching suspect" from a town west of Tarangire (LHRC 2015).

${ }^{12}$ MNR/C.5/4/4/Vol.4/134, 4/10/2013.

${ }^{13}$ Reducing Emissions from Deforestation and forest Degradation.
} 
to make both "resilient" to ecological, human demographic and economic stress. NTRI's partners suggest overcoming the separation of people from wildlife by focusing on restoring "coexistence of people, wildlife, and cattle."14 To achieve this ambitiously biopolitical goal, NTRI has introduced family planning and reproductive services, and it hopes to generate economic incentives from conservation-based enterprises, to secure livestock and wildlife grazing routes, and to support local communities in securing their land rights against external investors and immigrants. At the same time, NTRI works towards arresting land conversion to agriculture.

One of NTRI's first interventions aimed to redesign Makame Wildlife Management Area as a REDD+ project. Makame villages south-east of Tarangire are believed to harbor elephants and other wildlife that migrate from Tarangire National Park (Figure 2; Figure 6, left map, wildlife corridor \#7). After initial skepticism, Makame residents agreed to form a WMA in 2012 as a strategy to protect their land rights and grazing areas against in-migrants. To halt the influx of farmers, Maasai residents welcomed an eviction order that the district government issued in 2014 against everyone living and farming within the WMA. More recently, the NTRI member NGO Carbon Tanzania offered significant payments generated through the sale of carbon credits on the condition that the residents keep an agreed area free from deforestation or cultivation by themselves or by in-migrants, and police the designated area accordingly. Makame's REDD+ project is thus - similar to the Simanjiro easements - reinforcing Tarangire as an extensive conservation landscape that is inclusive and exclusive at the same time. Land use planning, economic incentives and policing are jointly employed to ensure that rural livelihoods remain compatible with the landscape conservation vision of a shared space for wildlife, people and their livestock, while keeping local cultivation in check, and keeping out people and livestock deemed as not belonging to the landscape.

\section{Conclusion}

In a conversation in 2015, the director of Mkungunero Game Reserve emphasized that "Game Reserves are established for ecosystem needs, not for administrative needs" (Interview 2015). This is a remarkable shift from a colonial territoriality of strict administrative separation of people and wildlife to enable rural development by controlling and exploiting nature, towards an ecologized neoliberal territoriality in which rural communities are restricted in their land use practices to allow nature to thrive and wildlife to roam free across a large landscape. Employing an analytic that I call a biopolitical ecology of conservation, this article has illustrated how this shift occurred historically in a biopolitics of 'making live' and 'letting die.' First, concerns for charismatic wildlife took on a global dimension, rendering formerly localized areas of wildlife population control as transnationalized spaces of biodiversity value. This re-valuation converged with the rise of conservation-based tourism as a key foreign exchange earner. Second, the emergence of conservation biology as a biopolitical science ecologized the way rural landscapes of production ought to be perceived. And third, conservation became neoliberalized through new funds and partnerships of state authorities, international donors, conservation biologists, private tourism investors and conservation NGOs. Combined, this conservation paradigm transformed the very idea about what constitutes appropriate human and nonhuman conduct and gave it a much different biopolitical meaning.

Today, rural people living around Tarangire are expected to conduct themselves in ways that are compatible with conservation ideals that dictate appropriate land use and environmental behavior so that wildlife can roam free. Similar to how colonial subjects were categorized into being differently close to nature, and thereby received different treatment by the colonial regime, contemporary conservation initiatives build on the categorization of different groups into those that are more, or less, compatible with conservation objectives. The boundary between who is an insider and who an outsider is thereby constructed based on the premise of conservation-compatible livelihoods. The dominant boundary-makers are state and non-state conservation actors, whose ideas about appropriate behavior and whose interests differ in significant ways. Given this diversity within landscape conservation initiatives, attention to rural livelihoods at times and in certain places renders rural people as more, or less, threatening to the environment. For instance, some conservationists and

\footnotetext{
${ }^{14}$ www.ntri.co.tz
} 
tourism entrepreneurs have celebrated Maasai communities overlapping with Simanjiro easements for being responsible pastoralists who are protecting important wildlife dispersal areas, while others have suspected the same people of undermining wildlife conservation. These diverging perceptions are equally animated by a landscape vision that invites different conservation actors to intervene in peoples' lives.

Biopower is thereby primarily exercised through the imperative of conservation-compatible livelihoods. In a biopolitics of making live, people perceived as being conducive to conservation objectives can stay, and their well-being becomes entangled with the management of the environment. They become enrolled in disciplinary measures, are offered economic incentives and to some extent secured land tenure under a strict land use planning regime. However, people whose conduct is deemed harmful (especially farmers, but often also pastoralists), are economically and physically excluded in a biopolitics of letting die. Wildlife, too, has been subjected to a shifting biopolitical rationality. During colonial rule, wildlife was killed as problem animals, or it was killed for pleasure as a game trophy. Today, problem animal control is not a priority, but trophy hunting continues, albeit governed by a different rationality. Individual animals are sacrificed through trophy hunting not simply for the pleasure of white hunters, but to protect the entire population.

I argue that a benevolent rendering of certain livelihoods as compatible with conservation (making live) cannot hide the inability of landscape conservation in advancing new imaginaries about alternative African futures, revealing a hierarchy of 'making live' between human and nonhuman species. The historical shift from governing people through agro-pastoral development towards governing through conservation has produced new demands on, and expectations towards, rural people who live in relative proximity to protected areas. Whereas under colonial or early post-colonial rule, rural people were primarily expected to be 'productive' farmers and land users, and were thus subjected to often ill-conceived development interventions, today they are primarily expected to be conservationists who refrain from exploiting land and 'natural' resources altogether. These unprecedented demands on highly land-dependent rural people constitute a sacrifice in relation to peoples' present and future needs and aspirations.

Ultimately, this biopolitical sacrifice rests on an asymmetric valuation of human and nonhuman species in the contemporary conjuncture of transnational neoliberal conservation. Seen through a biopolitical lens, landscape conservation is a governmental project to rearrange and fix in time and space human populations to allow wildlife to thrive at the population level in an unbounded, abstract space. This biopolitics is tied simultaneously to global environmentalist concerns and political economies of neoliberal conservation, as well as to a domestic agenda of economic growth through tourism-based foreign exchange. This conservation governmentality reinforces a political and socio-economic status quo of uneven development. In this conservation straightjacket, land-dependent rural people are at risk of becoming an increasingly land-deprived surplus population (Bluwstein et al. in press).

\section{References}

Adams, J.S. and T.O. McShane. 1992. The myth of wild Africa: conservation without illusion. Berkeley and Los Angeles: University of California Press.

Adams, W.M. 2004. Against extinction: the story of conservation. London: Earthscan.

Arlin, C. 2011. Becoming wilderness: a topological study of Tarangire, Northern Tanzania, 1890-2000. Ph.D. dissertation. Stockholm: Stockholm University.

AWF 1998. Landmark Project to protect Tarangire. October 1, 1998. African Wildlife Foundation.

AWF 2004. Annual report 2003. African Wildlife Foundation.

AWF n.d.-a. African Heartlands. African Wildlife Foundation.

AWF n.d.-b. AWF Heartland Conservation Process (HCP). African Wildlife Foundation.

Benjaminsen, T.A., M. J. Goldman, M.Y. Minwary and F.P. Maganga. 2013. Wildlife management in Tanzania: state control, rent seeking and community resistance. Development and Change 44(5): 1087-1109.

Bergin, P. 2001. Accomodating new narratives in a conservation bureaucracy. TANAPA and community conservation. In Hulme, D. and M.W. Murphree (eds.). African wildlife and livelihoods: the promise and performance of community conservation. Oxford: James Currey. Pp. 88-105. 
Biermann, C. and R.M. Anderson. 2017. Conservation, biopolitics, and the governance of life and death. Geography Compass 11(10): 1-13.

Biermann, C. and B. Mansfield. 2014. Biodiversity, purity, and death: conservation biology as biopolitics. Environment and Planning D: Society and Space 32(2): 257-273.

Bluwstein, J. 2017. Creating ecotourism territories: environmentalities in Tanzania's community-based conservation. Geoforum 83: 101-113.

Bluwstein, J. 2018. Biopolitical landscapes. governing people and spaces through conservation in Tanzania. Ph.D. dissertation, Department of Food and Resource Economics. Copenhagen: University of Copenhagen.

Bluwstein, J. and J.F. Lund. 2018. Territoriality by conservation in the Selous-Niassa Corridor in Tanzania. World Development 101: 453-465.

Bluwstein, J., J.F. Lund, K. Askew, H. Stein, C. Noe, R. Odgaard, F.P. Maganga and L. Engström. in press. Between dependence and deprivation: the interlocking nature of land alienation in Tanzania. Journal of Agrarian Change.

Bluwstein, J., F. Moyo and R. Kicheleri. 2016. Austere conservation: understanding conflicts over resource governance in Tanzanian Wildlife Management Areas. Conservation and Society 14(3): 218-231.

Boerstra, B. 2017. Internal territorialities: the role of law and conservation in state-citizen relations in Tanzania. M.Sc. dissertation. Copenhagen: University of Copenhagen.

Boesen, J., K. Havnevik, J. Koponen and R. Odgaard. 1986. Tanzania: crisis and struggle for survival. Uppsala: Nordic Africa Institute.

Bonner, R. 1994. At the hand of me: peril and hope for Africa's wildlife. New York: Vintage Books.

Borner, M. 1985. The increasing isolation of Tarangire National Park. Oryx 19(02): 91-96.

Brockington, D. 2002. Fortress conservation: the preservation of the Mkomazi Game Reserve, Tanzania. Oxford: James Currey.

Cavanagh, C.J. 2016. Anthropos into humanitas: civilizing violence, scientific forestry, and the 'Dorobo question' in eastern Africa. Environment and Planning D: Society and Space 35(4): 694-713.

Cavanagh, C.J. 2014. Biopolitics, environmental change, and development studies. Forum for Development Studies 41(2): 273-294.

Clay, N. 2016. Producing hybrid forests in the Congo Basin: a political ecology of the landscape approach to conservation. Geoforum 76: 130-141.

Collard, R.-C. and J. Dempsey. 2013. Life for sale? The politics of lively commodities. Environment and Planning A 45(11): 2682-2699.

Cosgrove, D.E. 1998. Social formation and symbolic landscape. Madison, WI: University of Wisconsin Press.

Davis, A. and M.J. Goldman. 2017. Beyond payments for ecosystem services: considerations of trust, livelihoods and tenure security in community-based conservation projects. Oryx: in press.

Death, C. 2016. Green states in Africa: beyond the usual suspects. Environmental Politics 25 (1): 116-135.

DeFries, R., S. Sharma and T. Dutta. 2016. A landscape approach to conservation and development in the Central Indian Highlands. Regional Environmental Change 16(1): 1-3.

Eckert, A. 2007. Herrschen und verwalten: afrikanische bürokraten, staatliche ordnung und politik in Tanzania, 1920-1970. München: R. Oldenbourg Verlag.

Forsyth, T.J. 2005. The political ecology of the ecosystem approach for forests. In J.A. Sayer and S. Maginnis (eds.). Forests in landscapes: ecosystem approaches to sustainability. London: Earthscan. Pp. 165-175.

Foucault, M. [1978] 1991. Governmentality. In M. Foucault, G. Burchell, C. Gordon and P. Miller (eds.). The Foucault effect: studies in governmentality.Chicago, IL: University of Chicago Press. Pp. 87-104.

Foucault, M. 2003. Society must be defended: lectures at the Collège de France. Trans. David Macey. New York: Picador.

Garland, E.C. 2006. State of nature: colonial power, neoliberal capital, and wildlife management in Tanzania. Ph.D. dissertation. Chicago: University of Chicago. 
GEF. 2003. Novel forms of livestock and wildlife integration around protected areas in Africa. Medium-Sized Project. Global Environmental Facility.

Goldman, M. 2009. Constructing connectivity: conservation corridors and conservation politics in East African rangelands. Annals of the Association of American Geographers 99(2):335-359.

Hagen, H. 1979. Nationalpark Tarangire. Greven: Kilda Verlag.

Henfrey, T.H. 1928. Is game preservation compatible with the agricultural development, with special reference to Tanganyika Territory. SPFE 8: 117-119.

Hingston, R.W.G. 1931. Proposed British National Parks for Africa. The Geographical Journal 77(5): 401-422.

Hodgson, D.L. 2001. Once intrepid warriors: gender, ethnicity, and the cultural politics of Maasai development. Bloomington, IN: Indiana University Press.

Holmes, G. and C.J. Cavanagh. 2016. A review of the social impacts of neoliberal conservation: formations, inequalities, contestations. Geoforum 75:199-209

Hurst, A.W. 2004. Not yet out of the woods: a political ecology of state forest policy and practice in mainland Tanzania, 1961-1998. Ph.D. dissertation. Oxford: University of Oxford.

Igoe, J. 2017. The spectacle of nature: on images, money, and conserving capitalism. Tucson, AZ: University of Arizona Press.

Igoe, J. and D. Brockington. 1999. Pastoral land tenure and community conservation: a case study from NorthEast Tanzania. Pastoral Land Tenure Series No. 11. London: IIED.

Igoe, J. and D. Brockington. 2007. Neoliberal conservation: a brief introduction. Conservation and Society 5(4): 432-449.

Igoe, J. and B. Croucher. 2007. Conservation, commerce, and communities: the story of community-based wildlife management areas in Tanzania's northern tourist circuit. Conservation and Society 5(4): 534561.

Ihucha, A. 2014. Human-wildlife conflict reduces number of lions in Tanzania. September 13, 2014. The EastAfrican.

Iliffe, J. 1979. A modern history of Tanganyika. Cambridge: Cambridge University Press.

IUCN 1963. Conservation of nature and natural resources in modern African states. CCTA and IUCN symposium, Arusha, Tanganyika, September 1961. Morges: IUCN.

IUCN. 1978. Categories, objectives and criteria for protected areas. Committee on Criteria and Nomenclature, Commission on National Parks and Protected Areas. Morges: IUCN.

Jones, T., T. Caro and T.R.B Devenport. 2009. Wildlife corridors in Tanzania. Unpublished report. Arusha: TAWIRI.

Kjekshus, H. 1996. Ecology control and economic development in East African history: the case of Tanganyika 1850-1950. London: James Currey.

Koponen, J. 1988. People and Production in Late Precolonial Tanzania: History and Structures. Helsinki: Finnish Society for Development Studies; Nordiska Afrikainstitutet

Lamprey, H. F. 1964. Estimation of the large mammal densities, biomass and energy exchange in the Tarangire Game Reserve and the Masai Steppe in Tanganyika. African Journal of Ecology 2(1):1-46.

Leader-Williams, N., J.A. Kayera and G.L. Overton. 1996. Tourist hunting in Tanzania. Proceedings of a Workshop held in July 1993. IUCN Species Survival Commission, Dar es Salaam, Tanzania: Department of Wildlife

Leader-Williams, N. 2000. The effects of a century of policy and legal change on wildlife conservation and utilisation in Tanzania. In H.H.T. Prins, J.G. Grootenhuis and T.T. Dolan (eds.) Wildlife conservation by sustainable use. Dordrecht: Springer Netherlands. Pp. 219-245.

Lee, D.E. and M.L. Bond. 2018. Quantifying the ecological success of a community-based wildlife conservation area in Tanzania. Journal of Mammalogy: gyy014-gyy014.

LHRC 2015. Operesheni Tokomeza Ujangili Report 2014. Dar es Salaam: Legal and Human Rights Centre.

Li, T.M. 2014. Fixing non-market subjects: governing land and population in the Global South. Foucault Studies 18: 34-48. 
Lorimer, J. 2015. Wildlife in the Anthropocene: conservation after nature. Minneapolis: University of Minnesota Press.

Loveless, S. 2014. Establishing WMAs in Tanzania: the role of community-level participation in the making of Randileni WMA. M.Sc. thesis. Copenhagen: University of Copenhagen.

Luke, T.W. 1995. On environmentality: geo-power and eco-knowledge in the discourses of contemporary environmentalism. Cultural Critique (31): 57-81.

MacKenzie, J.M. 1988. The empire of nature: hunting, conservation, and British imperialism. Manchester: Manchester University Press.

Masara, Y.B. 2005. Wildlife areas expansion and local land rights: The Case of Kimotorok Village, Simanjiro District. Dar es Salaam: PINGOs Forum.

McCall, M.K. 2016. Beyond "landscape" in REDD+: the imperative for "territory". World Development 85: 5872.

Mitchell, W.J.T. 2002. Landscape and power. Second Edition. Chicago: University of Chicago Press.

MNRT. 1994. Policy for management of the African Elephant in Tanzania. Dar es Salaam, Tanzania: Department of Wildlife, Ministry of Natural Resources and Tourism.

Msoffe, F.U., S.C. Kifugo, M.Y. Said, M.O. Nessele, P. van Gardingen, R.S. Reid, J.O. Ogutu, M. Herrero and J. De Leeuw. 2011. Drivers and impacts of land-use change in the Maasai Steppe of northern Tanzania: an ecological, social and political analysis. Journal of Land Use Science 6(4): 261-281.

Mwalyosi, R.B.B. 1991. Ecological evaluation for wildlife corridors and buffer zones for Lake Manyara National Park, Tanzania, and its immediate environment. Biological Conservation 57(2): 171-186.

Myers, N. 1988. Threatened biotas: "hot spots" in tropical forests. Environmentalist 8(3): 187-208.

Nash, R. 1982. Wilderness and the American mind. New Haven, CT: Yale University Press.

Nel, A. 2015. The choreography of sacrifice: market environmentalism, biopolitics and environmental damage. Geoforum 65: 246-254.

Neumann, R.P. 1998. Imposing wilderness: struggles over livelihood and nature preservation in Africa. Berkeley and Los Angeles, CA: University of California Press.

Neumann, R.P. 2001. Africa's 'last wilderness': reordering space for political and economic control in colonial Tanzania. Africa 71(4): 641-665.

Neumann, R.P. 2002. The postwar conservation boom in British Colonial Africa. Environmental History 7(1): 22-47.

Neumann, R.P. 2004a. Nature-State-Territory: towards a critical theorization of conservation enclosures. In R. Peet and M.J. Watts (eds.). Liberation ecologies: environment, development and social movements. London: Routledge. Pp. 179-199.

Neumann, R.P. 2004b. Moral and discursive geographies in the war for biodiversity in Africa. Political Geography 23(7): 813-837.

Offen, K. H. 2004. Historical political ecology: an introduction. Historical Geography 32: 19-42.

Prins, H.H.T. 1987. Nature conservation as an integral part of optimal land use in East Africa: The case of the Masai ecosystem of Northern Tanzania. Biological Conservation 40(2): 141-161.

Rabinow, P. and N. Rose. 2006. Biopower today. BioSocieties 1(2): 195-217.

Risser, P.G. 1984. Landscape ecology: directions and approaches. Champaign, IL: Illinois Natural History Survey.

Robi, A. 2016. Human activities risk wildlife in Tarangire National Park. 18 December 2016. Daily News Tanzania.

Robson, A. S., M.J. Trimble, A. Purdon, K.D. Young-Overton, S.L. Pimm, and R.J. van Aarde. 2017. Savanna elephant numbers are only a quarter of their expected values. PLOS ONE 12 (4):e0175942.

Rose, G. 1993. Feminism and geography: the limits of geographical knowledge. Cambridge: Polity Press.

Rutherford, S. 2007. Green governmentality: insights and opportunities in the study of nature's rule. Progress in Human Geography 31(3): 291-307. 
Sachedina, H.T. 2011. Disconnected nature: the scaling up of African Wildlife Foundation and its impacts on biodiversity conservation and local livelihoods. In D. Brockington and R. Duffy (eds.). Capitalism and conservation. Oxford: Wiley-Blackwell. Pp. 135-155.

Sachedina, H. 2008. Wildlife is our oil: conservation, livelihoods and NGOs in the Tarangire Ecosystem, Tanzania. Ph.D. dissertation. Oxford: University of Oxford.

Sachedina, H. and F. Nelson. 2010. Protected areas and community incentives in savannah ecosystems: a case study of Tanzania's Maasai Steppe. Oryx 44(03): 390-398.

Sale, K. 1985. Dwellers in the land: the bioregional vision. Athens, GA: University of Georgia Press.

Sayer, J.A., C. Margules, A.K. Boedhihartono, T. Sunderland, J.D. Langston, J. Reed, R. Riggs, L.E. Buck, B.M. Campbell, K. Kusters, C. Elliott, P.A. Minang, A. Dale, H. Purnomo, J.R. Stevenson, P. Gunarso and A. Purnomo. 2016. Measuring the effectiveness of landscape approaches to conservation and development. Sustainability Science 12(3): 465-476.

Scott, J.C. 1998. Seeing like a state: how certain schemes to improve the human condition have failed. New Haven, CT: Yale University Press.

Shetler, J.B. 2007. Imagining Serengeti: a history of landscape memory in Tanzania from earliest times to the present. Athens, OH: Ohio University Press.

Shivji, I. (ed.). 1975. Tourism and socialist development. Dar es Salaam: Tanzania Publishing House.

Srinivasan, K. 2014. Caring for the collective: biopower and agential subjectification in wildlife conservation. Environment and Planning D: Society and Space 32(3): 501-517.

Sundet, G. 1997. The politics of land in Tanzania. Ph.D. dissertation. Oxford: University of Oxford.

Sunseri, T. 2009. Wielding the ax: state forestry and social conflict in Tanzania, 1820-2000. Athens, OH: Ohio University Press.

Svarstad, H. and T.A. Benjaminsen. 2017. Nothing succeeds like success narratives: a case of conservation and development in the time of REDD. Journal of Eastern African Studies:1-24.

TANAPA. 1994. National policies for National Parks in Tanzania. Arusha, Tanzania: TANAPA.

TANAPA. 1998. TANAPA planning workshop for the activities in the Tarangire/Lake Manyara Complex. Arusha, Tanzania: TANAPA.

TAWIRI. 2010. Tanzania Elephant Management Plan 2010-2015. Arusha, Tanzania: TAWIRI.

TAWIRI. 2014. Elephant population estimate in Tanzania. Countrywide African Elephant survey 2014. Arusha, Tanzania: TAWIRI.

TAWIRI. 2015. Aerial eensus of elephant in Tarangire-Manyara ecosystem, Tanzania. Dry Season 2014. TAWIRI Aerial Survey Report. Arusha, Tanzania: TAWIRI.

TNRF. 2008. Wildlife for all Tanzanians. Information pack and policy recommendations. Arusha, Tanzania: TNRF.

URT. 1994. Report of the Presidential Commission of Inquiry Into Land Matters. Volume I. Land policy and land tenure structure. Uddevalla, Sweden: Ministry of Lands, Housing and Urban Development, United Republic of Tanzania.

URT. 2009. Wildlife Conservation Act No.5 of 2009. Dar es Salaam: United Republic of Tanzania.

USAID. 2004. USAID/Tanzania Country Strategic Plan FY 2005-2014. Improving the quality of life in Tanzania. Washington DC: USAID.

USAID. 2014. Performance evaluation of SCALE-TZ Project. Final evaluation report. Washington DC: USAID.

Waage, E.R.H. and K. Benediktsson. 2010. Performing expertise: landscape, governmentality and conservation planning in Iceland. Journal of Environmental Policy and Planning 12(1): 1-22.

Weiskopf, J.M. 2015. Socialism on safari: wildlife and nation-building in postcolonial Tanzania, 1961-77. The Journal of African History 56(3): 429-447.

Wels, H. 2015. Securing wilderness landscapes in South Africa: Nick Steele, private wildlife conservancies and saving Rhinos. Leiden, NL: Brill. 
West, P., J. Igoe and D. Brockington. 2006. Parks and peoples: the social impact of Protected Areas. Annual Review of Anthropology 35(1): 251-277.

Willems-Braun, B. 1997. Buried epistemologies: the politics of nature in (post)colonial British Columbia. Annals of the Association of American Geographers 87(1):3-31.

Xinhua. 2017. Tanzania mulls relocating invaders of wildlife corridors. 24/9/2017 Xinhua 